\title{
Floristic biodiversity, biogeographical significance, and importance of Morocco's Arganeraie Biosphere Reserve
}

\author{
Fouad Msanda $^{1}$ (D) El Hassan Mayad ${ }^{1} \cdot$ James Nicolas Furze $^{1,2,3}$ \\ Received: 26 August 2020 / Accepted: 1 December 2020 / Published online: 6 January 2021 \\ (C) The Author(s), under exclusive licence to Springer-Verlag GmbH, DE part of Springer Nature 2021
}

\begin{abstract}
The coastal and subcoastal areas of west-central Morocco (Safi to Draa River, the Souss Valley, and the southern part of the western High Atlas and northern and southern slopes of the western Anti-Atlas) are characterized by typical Infra-Mediterranean vegetation ranking them amongst the important of the remarkable borderlands of North Africa. The flora is determined by complex historical and environmental factors occurring since the Tertiary period. The originality of this sector is due to the presence of the argan tree (Argania spinosa (L.) Skeels), Moroccan gum (Acacia gummifera Willd), olive trees (Olea europaea L. subsp. maroccana (Greuter \& Burdet) P. Vargas \& al.), a thermophilic flora adapted to an arid climate with several endemic species. This flora constitutes the final barrier against the desert and is of environmental and socioeconomical interest. Leaves and fruits provide forage material, while wood is used for fuel. Argan fruits are collected for their oily constitutes and for nutritional, cosmetic, and medicinal properties. Additionally, many species of Argan ecosystems are used in medicine and cosmetics. Recognizing its ecological value and local economic importance, the Argan region was declared a UNESCO Biosphere Reserve in 1998. Despite their biogeographical, historical, and socioeconomic value, vegetation structures in west-central Morocco are vulnerable and threatened by human activities. They exhibit high levels of degradation due to increasing clearance, overgrazing, and overexploitation. The area requires high conservation priority and sustainable management strategies for key species and genetic diversity.
\end{abstract}

Keywords Argania spinosa $\cdot$ Biodiversity $\cdot$ Aromatic $\cdot$ Medicinal plants $\cdot$ Argan Biosphere $\cdot$ Strategies

\section{Introduction}

The west-central part of Morocco, between $32^{\circ} \mathrm{N}$ and $29^{\circ} \mathrm{N}$ latitude, has a rich and diversified flora and is characterized by a considerable number of endemic species. The sector covers an area of 2,560,000 ha representing all of the Arganeraie Biosphere Reserve. The region is in the transitional area

Responsible Editor: Philippe Garrigues

Fouad Msanda

f.msanda@uiz.ac.ma

1 Faculty of Sciences, Laboratory of Biotechnology and Valorization of Natural Resources, Agadir, Morocco

2 Control and Systems Engineering Department, University of Technology, Baghdad, Alsinaah Street, P.O. Box: 19006, Baghdad 10066, Iraq

3 Royal Geographical Society (with the Institute of British Geographers), 1 Kensington Gore, London SW7 2AR, UK between the Mediterranean iso-climatic zone in the north and the Saharan region in the south and has a wide opening to the Atlantic Ocean. The flora is mostly made up of Mediterranean taxa, coexisting with tropical, Saharan, Macaronesia, and endemic taxa (Msanda et al. 2005). A total of 1440 plant taxa have been recorded, and some parts of this area have acted as major refugia for the tertiary paleoflora (Médail and Quézel 1999). Within the area, endemism represents 140 species and subspecies (Peltier 1982; M'hirit et al. 1998).

The basis of flora in the Arganeraie stems from the argan tree (Argania spinosa), several succulent taxa and thermophilic flora, which are well adapted to the particularly arid climate (Euphorbia officinarum L. subsp. officinarum, E. officinarum L. subsp. echinus (Hooker fil. \& Cosson) Vindt, Kleinia anteuphorbium (L.) Haw., Aeonium arborescens (L.) Webb $\&$ Berth., Apteranthes burchardii (N. E. Br) Plowes subsp. maura (Maire) Meve \& Liede, Astydamia latifolia (L. fil.) Baillon). A. spinosa, Olea europaea subsp. maroccana and Dracaena draco L. subsp. ajgal Benabid and Cuzin 1997 are 
significant endemic trees of west-central Morocco (Médail and Quézel 1999; Médail et al. 2001; Msanda et al. 2005). At high altitudes in the area, argan trees are replaced by holm oak (Quercus ilex L. subsp. rotundifolia (Lam.) T. Morais), and juniper (Juniperus oxycedrus L.). Finally, a large number of aromatic and medicinal plants are present in the argan Biosphere Reserve. Members of the wild flora play an important socioeconomic role in the life and activities of local people.

The biogeographic, biodiversity, and economic importance of the flora and vegetation in the area has been widely studied (Emberger and Maire 1932; Capot-Rey 1952; Guinet and Sauvage 1954; Boudy 1958; Dubief 1963; Sauvage 1963; Quézel 1965; Chaumat 1977; Donadieu 1977; Barbéro et al. 1981; Barbéro et al. 1982; Peltier 1982, 1986; Coquillard 1983; Michalet 1991; El Aboudi et al. 1992; Msanda 1993; Quézel et al. 1994; Quézel 1995; Peltier and Msanda 1995; Benabid and Cuzin 1997; M'hirit et al. 1998; Médail and Quézel 1999; Benabid 2000; Msanda et al. 2002, 2005; Lybbert 2007; Lybbert et al. 2011).

The aim of this paper is to provide an overview of the vegetation of the Arganeraie of west-central Morocco thereby highlighting its biogeographical and socioeconomic value, justifying heightened priorities of management. We also hope to account for the unique, emergent function of the vegetation which promotes surrounding diversity on a huge scale.

\section{Floristic diversity and phytogeographical aspects}

Key floristic diversity of the Argan Biosphere is featured, with mention to inter related climatic factors, coining unique opportunities for diversity and its generation into the future.

The argan tree (A. spinosa) is a member of the tropical family Sapotaceae, endemic to Morocco and constitutes one of the most remarkable trees in North Africa (Médail and Quézel 1999; Khallouki et al. 2017). Located in the westcentral part of Morocco, argan forest occupies approximately 800,000 ha (Fig. 1). Argan tree is widely distributed from Safi in the north to Draa River in the south, and both in the Souss plain and the High and Anti-Atlas piedmont (Peltier 1982). The tree growth extends from sea level up to $1300-1500 \mathrm{~m}$. The altitudinal limit of the argan tree corresponds to the monthly minimum temperature of the coldest month, $3.8^{\circ} \mathrm{C}$ (Emberger 1925). In recognition of its ecological value and local economic importance, in 1998 UNESCO declared the area as a Biosphere Reserve.

Seed dispersal via both animal and human carriers has resulted in the argan tree having two discrete lineages: one of which is located in the south-east of Rabat (Grou Valley), the other of which is in the north-west of Morocco (Beni-Snassen, Oujda) (El Mousadik and Petit 1996).
The climate is Mediterranean, characterized by great seasonal variations marked by hot and dry summers with cold and rainy winters (Emberger 1955). Globally, the area can be divided into two bioclimatic domains, the first of which corresponds to the coastal and subcoastal sectors. Extending from Safi in the north, to the Draa River in the south and including the Souss plain, the southern slope of the western High Atlas and the northern slope of the western Anti-Atlas, have altitudes close to $800 \mathrm{~m}$. This domain is subject to the prevalence of maritime trade winds, particularly in summer (Delannoy 1996). Due to the oceanic influence, fog and mist are frequent and atmospheric humidity exceeds $85 \%$ for many months of the year, mainly in summer and autumn (Delannoy 1975, 1980). Occult precipitations constitute an important factor related to remarkably dense vegetation. Precipitation levels vary between 100 and $400 \mathrm{~mm}$ according to the location and the altitude. The littoral sector is characterized by moderate temperatures $\left(18.5^{\circ} \mathrm{C}\right.$ annual average in Agadir and Sidi Ifni) while the inland parts show high values $\left(19.7^{\circ} \mathrm{C}\right.$ annual average in Taroudant). The boundaries of this domain are those of the inframediterranean belt.

The second bioclimatic domain of the argan biosphere corresponds to the mountains in the western part of High Atlas and northern slopes of the western Anti-Atlas, which are exposed to Atlantic influences and affected by the North Atlantic Oscillation (Delannoy 1988). The climatic characteristics, for lack of an appropriate climatic network, are still difficult to specify. However, the high altitudes receive relatively high amount of precipitation, estimated at 500 to $600 \mathrm{~mm}$, and high cloudiness linked to the North Atlantic Oscillation. This domain corresponds, globally, to the Thermo-Mediterranean belt and locally to the Meso-Mediterranean.

Plant biodiversity of argan woodlands reflects its biogeographic heterogeneity where Mediterranean, tropical, succulent, and endemics taxa coexist (Msanda et al. 2005). The current flora results from paleoclimatological, paleoecological, and paleogeographical influences persisting since the Tertiary. In fact, some parts of the west-central of Morroco are considered as a refuge for tertiary flora, particularly for African thermo-xerophile taxons (Médail and Quézel 1999; Médail and Diadema 2009). On the Atlantic coast, crassulescent and aphyllous taxa are well represented. They include E. officinarum subsp. officinarum, A. burchardii (N. E. Br.) Plowes subsp. maura (Maire) Meve \& Liede, Orbea decaisneana var. hesperidum (Maire) Jonkers, Apteranthes joannis (Maire) Plowes., A. arborescens and A. latifolia. Macaronesian elements, linked to the Infra Mediterranean belt, are represented by several plants. The most important species are Davallia canariensis (L.) Sm., Asparagus pastorianus Webb \& Berthel., Bassia tomentosa (Lowe) Maire \& Weiller, Artemisia reptans Bush, Helianthemum canariense (Jacq.) Pers., Andryala pinnatifida subsp. mogadorensis (Hook. f.) Greuter, Sonchus pinnatifidus 
Fig. 1 Argan tree area

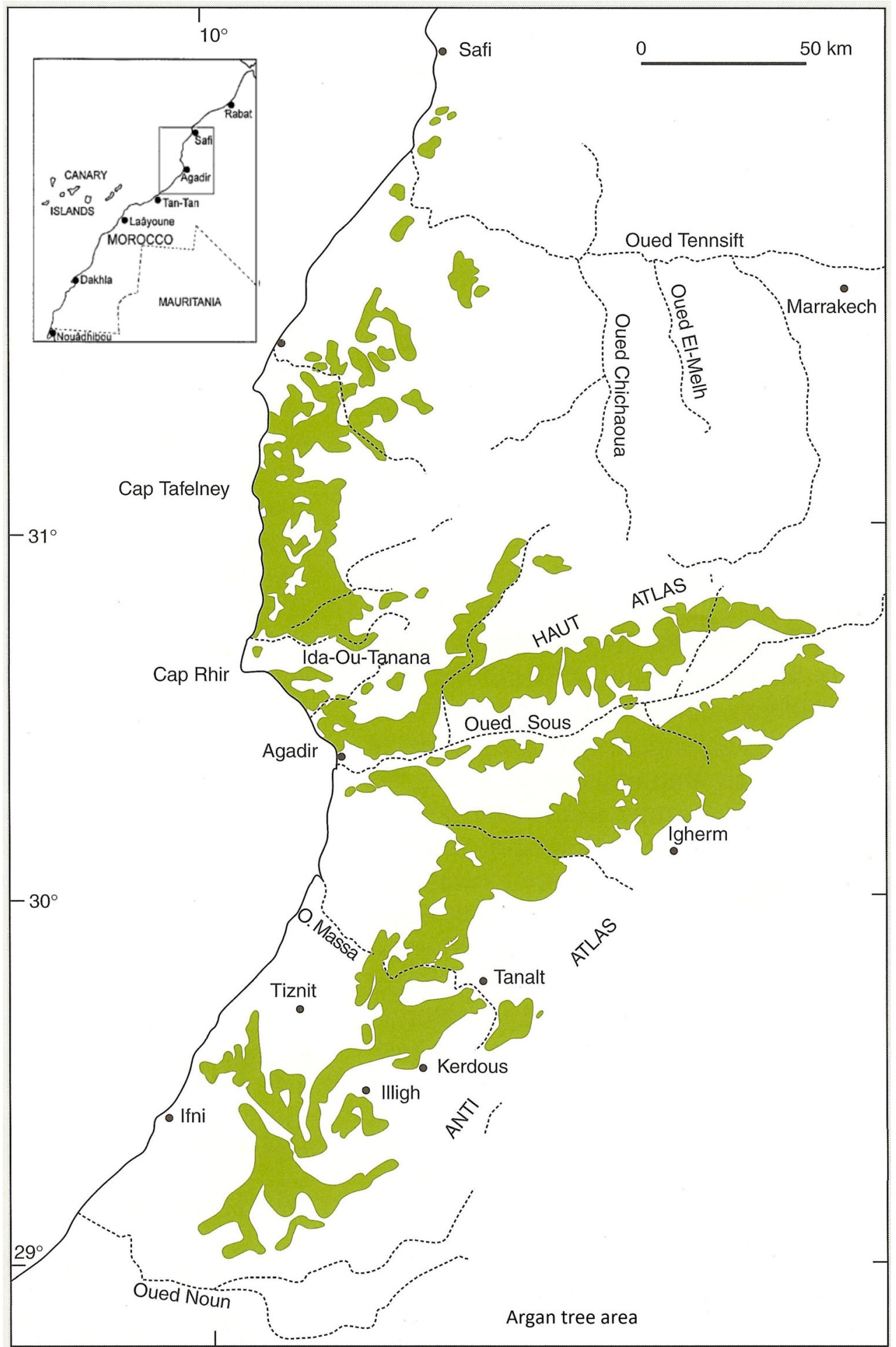

(Cav.), Asteriscus imbricatus (Cav.) DC. and Asteriscus schultzii (Bolle) Pitard \& Proust. Médail and Quézel (1999) listed 28 endemic taxa shared between this area and the Canary Island. The presence of Macaronesian taxa highlighted similarities between this region and the Canary Islands (Emberger 1939; Peltier 1982; Barbéro et al. 1982). Based on these similarities, several authors have identified a
Moroccan Macaronesian sector (Peltier 1982; Kim et al. 1996). Despite the floristic similarity, the phytogeographical spectra and species' life attributes, the coastal, and subcoastal Moroccan sector belong to the Mediterranean region and are not considered a Macaronesian sector (Médail and Quézel 1999; Msanda et al. 2005). Vegetation structure would date from the Mio-Pliocene (Quézel and Barbéro 1993), and the 
idea of a relationship of continuity between the African continent and the Canary Islands must be abandoned (Quézel 2000). Many species of tropical origin (Mathez 1973) are represented in the sector: Acacia gummifera, Commelina rupicola Font Quer, Kalanchoë laciniata (L.) DC. subsp. faustii (Font Quer) Maire, Leptochloa ginae (Maire), Andropogon distachyos L., Hyparrhenia hirta (L.) Stapf, Tricholaena teneriffae (L. f.) Link and Enteropogon rupestris (J. A. Schmidt) A. Chev, these taxa are currently located in residual stations (Benabid and Cuzin 1997). The presence of tropical taxa highlights the possibility of floristic exchanges between the Mediterranean and Tropical regions, since the Tertiary period. Saharo Arabian taxa representing southern infiltrations are represented by several species; for example Traganopsis glomerata Maire \& Wilczeck and Fagonia harpago Emberger \& Maire are two endemics and remarkable species, which appears in some parts of the Anti-Atlas. The area contains 140 endemic species, which have a Mediterranean origin (Médail and Quézel 1999): notably Chamaecytisus mollis (Cav.) Greuter \& Burdet, Genista ifniensis A. Caballero, Bupleurum dumosum Cosson \& Balansae, Hesperolaburnum platycarpum (Maire) Maire, Lavandula maroccana Murb., Sideritis cossoniana Ball and Thymus leptobotrys Murb. However several endemic species are specific to the argan sector, including E. officinarum subsp. officinarum, Teucrium tananicum Maire, D. draco subsp. ajgal, O. europaeae subsp. maroccana, Thymus broussonnetii Boiss. subsp. hannonis (Maire) R. Morales, Teucrium werneri Emberger, A. joannis, Lavandula rejdali Upson \& Jury, where many species are well represented in rupicolous communities (Médail and Quézel 1999).

A. spinosa, O. europaeae subsp. maroccana, and D. draco subsp. ajgal are significant endemic trees of west central Morocco. O. europaea subsp. maroccana is an endemic and relictual subspecies, which is located in the western part of the High Atlas and in the western part of the Anti-Atlas. $O$. europaea subsp. maroccana is very close to O. europaea L. subsp. guanchica P Vargas et al. of Canary Islands (Médail et al. 2001), and associates with the argan tree in an endemic phytocenosis (the association of Oleo maroccanaeArganietum spinosae (Barbéro et al. 1982) (Médail et al. 2001).

D. draco subsp. ajgal is located in the Assif Oumaghouz mountain in the Anti-Atlas (Benabid and Cuzin 1997), participates in an original and endemic association constituted by Davallio canariensis-Dracaenetum ajgal Benabid and Cuzin 1997. It is characterized by $D$. draco subsp. ajgal, which is an endemic and very rare sub-species (Fennane and Ibn Tattou 1998), D. canariensis and various endemics. According to Médail and Quézel (1999) the population of $D$. draco subsp. ajgal is representative case for North Africa of a refuge for tertiary flora. However, a recent study (Durán et al. 2020) claimed that D. draco subsp. ajgal may be a taxon at early stages of speciation differentiated from the island source area.

The mountains in the western part of High Atlas and northern slopes of the western Anti-Atlas, which are exposed to Atlantic influences are characterized by the presence of the thuya (Tetraclinis articulata (Vahl) Masters the holm oak Q. ilex subsp. rotundifolia, the Juniper (J. phoenicea) and the development of lavender matorrals (Lavandula dentata L. and Lavandula pedunculata (Miller) Cav.), Cistus (C. creticus L. and C. salviifolius L.) broom (Genista tricuspidata Desf.) and Cytise (Teline segonnei (Maire) C. Raynaud endemic to Kerdous and Ifni massif. The thuya formations grow in the N and NW exposures of the High western Atlas from $600 \mathrm{~m}$ altitude in the Ida Ou Tanane massif, the regions of Tamanar, Ait Daoud, and Jbel Amsittene (Fennane 1988). Depending on ecological conditions, the main trees associated to the thuya are A. spinosa, Ceratonia siliqua L., and Q. ilex subsp. rotundifolia. In the Western Anti-Atlas, in the Lakhsass massif, the thuya tree associated to argan tree and E. officinarum subsp. echinus constitute the southernmost association of thuya in Morocco (Fennane 1988). Ecologically, it is the most xerophilic association of thuya in Morocco which is located in an arid bioclimate with 250 to $300 \mathrm{~mm}$ precipitation per year. Although higher in altitude, the holm oak (Q. ilex subsp. rotundifolia) appears and participates in several plants associations. In the Western Anti Atlas (Jbels Bou Timezguida 1250 m, Bou Krat 1217 m, Touwala $1222 \mathrm{~m}$ in Ifni Massif, Lkest 2374 m, Ighchene 2041, Mkorn $2340 \mathrm{~m}$ in Kerdous Massif) relinked sites of holm oak, which constitute the most southern holm oak formations of Morocco are found (Peltier 1982; Msanda et al. 2002). These massifs are well known by their plant biodiversity and endemism (Mathez 1973; Peltier 1982; El Aboudi 1987).

\section{Role and successive woodland importance of the Arganeraie Biosphere Reserve}

The argan tree and the vegetation of the west-central of Morocco are of great importance at ecological, economic, and social levels and play a very important role in the subsistence of rural populations. The population is around 3 million people, of which 2.2 million in rural areas depend directly on the exploitation of argan forest (Laaribya et al. 2017).

The argan woodlands have multiple roles and uses. They perform a variety of ecosystem services, the most important being carbon storage and sequestration, habitat for species, conservation of genetic diversity, food and water, securing soil fertility, prevent soil erosion, regulation of microclimate, and local hydrological processes and tourism (Karmaoui 2016). Argan forests provide the final barrier against desertification (M'hirit et al. 1998; Msanda et al. 2005) and are essential to the population who depend on the vegetation for 
firewood and charcoal for heating and cooking, fodder for livestock, for cosmetic and medicinal purposes.

The Argan woodland is exploited for cereal crops, together with vegetables and legumes. Indeed, $90 \%$ of the rural economy in the region depends on argan-based agroforestry (Benchekroun and Buttoud 1989). In addition, the argan tree, the most remarkable tree of the landscape, provides a highly appreciated and expensive oil used in culinary, cosmetic, and medicinal purposes (Nouaïm et al. 1991; El Monfalouti et al. 2010; Lybbert et al. 2011).

Due to the interest of argan oil and with the objective to reduce rural poverty and to conserve the argan forest, women's cooperatives were created with the support of the Moroccan state and foreign organizations, since the 1990s (Sguenfle and Sadki 2018). Cooperatives have remarkably contributed to local economic development, social status of women and environmental preservation outcomes (Dossa 2011). Thus the argan forest constitutes a very important part in household income. Recently, argan oil price has almost quadrupled to reach more than 300 dirhams for a liter (30\$) on the local markets and more than 3000 dirhams (300\$) per liter in export booming market (Lybbert et al. 2011; Aziz et al. 2013; Le Polain de Waroux 2013). Several studies have shown that by 2027 , this market will register an annual growth of $10.8 \%$ tons of oil produced entirely by women (Lybbert et al. 2011; Grand View Research 2020). Actually, according to the Moroccan Cooperation Development Office (ODCO), there are more than 400 argan oil cooperatives, $93 \%$ of which were created by women and provide regular income for more than 7000 producers. The organization into cooperatives has allowed many women to have bank account and to reinvest in micro-projects like poultry, sheep, and goat farming (Roumane 2017). In addition, this development had a positive impact on the education of girls with a clear increase in enrollment in schools (Lybbert et al. 2011). However, it should be noted that the added value of the oil market benefits to educated managers, intermediaries, industry executives, and distributors more than women who produce the oil (Turner 2014; Montanari and Bergh 2019). Else, argan woodlands provide various economic opportunities in relationship with ecotourism and local products which can contribute to socioeconomic development of rural communities (Laaribya et al. 2017).

Climatic conditions and alternation phenomenon strongly influence Moroccan production of argan fruits with important variations from one year to another (Aithammou et al. 2019). Production of fruits is at its maximum when the tree is 60 years old, and the average yield of fruit per tree is estimated to $8 \mathrm{~kg} /$ year (Zrira 2017). Low yield of oil (2-2.5 1/100 kg of dried fruit in $58 \mathrm{~h}$ of manual extraction) (Charrouf and Guillaume 2008) encouraged a mechanized approach. This process has improved oil quality with extraction yield and reduced the time required for oil extraction (Charrouf and
Guillaume 1999; Hilali et al. 2005). The world market for argan oil enables a trade of 4835 tons (Khallouki et al. 2017) and export prices reach over US\$400/1 (Le Polain de Waroux 2013). The nutritional quality of the oil is due to the presence of a high percentage of unsaturated fatty acids especially oleic and linoleic acids (Yaghmur et al. 1999; Khallouki et al. 2003).

Medicinal benefits and properties of argan oil support its use as a dietary supplement. Drissi et al. (2004) have shown that regular consumption of virgin argan oil, in ninety-six subjects, has a LDL-cholesterol lowering effect together with antioxidant properties, and can play an important role in the prevention of cardiovascular risk. Similar results have been obtained in rats after treatment with argan oil (Berrada et al. 2000; Berrougui et al. 2003). Antioxidant effects of argan oil and argan fruits extracts have been proven in several studies (Cherki et al. 2006; El Babili et al. 2010; El Midaoui et al. 2016). This activity is due to the high contents of antioxidants as polyphenols, tocopherols, and sterols (Masella et al. 2001). The antioxidant properties of argan oil have revealed that the polyphenols and sterols present in oil have an inhibitory action on the proliferation of prostate cancer cell lines (Bennani et al. 2007). Additionally, the ethyl acetate extract and the decoction of argan fruits showed interesting antimalarial and antioxidant activities (El Babili et al. 2010). Argan oil is used traditionally as a cosmetic to treat hair, nail, and skin (El Monfalouti et al. 2010). Moukal (2004) reports that argan tree leaves have been used traditionally for their antipyretic and antiinflammatory properties, argan wood for its gastroprotective properties and reports the use of press cake as a shampoo and for its antiscabies properties.

In addition, the flora of the west-central Morocco is characterized by the presence of additional aromatic and medicinal plants that are widely used to treat illness; in fact, the population has a long tradition in the field of phytotherapy (Abouri et al. 2012; Barkaoui et al. 2017; Katiri et al. 2017; Idm'hand et al. 2020). The number of aromatic and medicinal plants is about three hundred with only a few of them being exploited. Further studies are needed to investigate biological activity and confirm their effectiveness in the human health care system and in industrial uses. These plants constitute a significant source of revenue for local populations; indeed some plant species are known of economist interest and are commercialized nationally and internationally. In Morocco, medicinal and aromatic plants play a very important socioeconomic role with annual revenues for export of about approx. 55.9 million dollars and provide 500,000 work days per year for local population (H.C.E.F.L.C.D. 2012; Montanari 2019). In addition to the argan tree, additional species in high demand in westcentral of Morocco include Thymus satureioides Cosson, A. herba-alba Asso, Mentha suaveolens subsp. timija (Coss. 
ex Briq.) Harley, Marrubium vulgare L., C. creticus, L. dentata, Ziziphus lotus L., C. siliqua, and O. europaea L. Amongst these species $T$. satureioides and A. herba-alba are well known for their medicinal uses and socioeconomic value.

In west-central Morocco, T. satureioides grows in arid and semiarid bioclimates, and is traditionally used to treat various ailments such as bronchitis, diabetes, colds, diarrhea, digestive disorders, rheumatism, fever, wounds, dermatisis, and hypertension (Bellakhdar et al. 1991; Abouri et al. 2012; Barkaoui et al. 2017; Katiri et al. 2017). T. satureioides is known for its antioxidant, antispasmodic, antimicrobial and antiinflammatory properties (Ismaili et al. 2004; Ramchoun et al. 2015). For its different uses, T. satureioides is taken as fresh or dried herbal tea decoction or infusion (Abouri et al. 2012).

In the west central region of Morocco, A. herba-alba is widely distributed spatially in highlands of the inlands in the High Atlas and Anti-Atlas. The species is the most common medicinal plant in Morrocco (Zrira 2017). A. herba-alba is used in traditional medicine to treat various diseases as helminthiasis, diabetes mellitus, colds, gastric pains, rheumatic diseases and possess spasmolitic, carminative, emmenagogue, diuretic, sedative, intestinal antiseptic, cholagogue, antihypertensive antimicrobial, antioxidant, antispasmodic, neurological, and pesticidal activities (Eddouks et al. 2002; Imelouane et al. 2010; Mohamed et al. 2010; Abouri et al. 2012; Barkaoui et al. 2017; Katiri et al. 2017; Zrira 2017). The plant is widely used in pharmaceutics, cosmetics perfumery, and food industry and suggested to be important as a fodder for sheep and for livestock (Taleb 2017; Zrira 2017) and Morocco holds $90 \%$ of the global market (Taleb 2017). T. satureioides and $A$. herba-alba are harvested from wild sources and constitutes a precious source of income for communities. For these plants therapeutic properties have been established scientifically. Khouya et al. (2019) showed that extracts from leaves of $T$. satureioides develop antiinflammatory activity in animal models and limit cancer cell proliferation in in vitro assays. Aqueous extracts, total polyphenols and total flavonoids of $T$. satureioides give marked antioxidant and antihemolytic activities in erythrocytes of rabbit blood (Ramchoun et al. 2015). Several studies have reported antimicrobial, antifungal, and antioxidant activity of $T$. satureioides essential oils (Jamali et al. 2013; Boubaker et al. 2016) due to the rich content of thymol borneol and carvacrol.

Extracts of $A$. herba-alba (essential oils, water, and ethyl acetate extracts) showed strong cytotoxicity against cancer cell proliferation (Jaouadi et al. 2014; Tilaoui et al. 2015; Bourgou et al. 2017). Aqueous extracts have been seen to have antihypertensive qualities in rats (Zeggwagh et al. 2008). Antioxidant activity of essential oils has been showed in several studies; this effect is due to the richness of phenolic compounds (Tawaha et al. 2007; Akrout et al. 2010). Recent published work on chemical composition of $A$. herba-alba concluded that the high content of oxygenated monoterpenes characterizing in its essential oil may qualify this plant as a potential source of antiviral molecules especially against COVID-19 (Asdadi et al. 2020).

Despite its importance, the argan biosphere agroforestry system is ecologically fragile, and its durability is threatened mainly by anthropogenic impacts and climate change. In mountains, the main factors of degradation are overgrazing and overexploitation (Nouaïm et al. 1991; Nouaim et al. 2002). In Souss and Chtouka plains, the expansion of irrigated and intensive agriculture has caused a drastic decrease of groundwater resources and induced dramatic degradation of natural resources. Droughts, overgrazing, and urbanization constitute a major cause of the decrease of natural resources in the west-central Morocco (El Abidine 2003; Naggar and Mhirit 2006; Mateille et al. 2016; Chakhchar et al. 2017). Several studies conducted in the region have reported widespread degradation in the argan forest since the first part of the twentieth century (Boudy 1958; Monnier 1965). Indeed, almost one-half of the argan forest disappeared during the twentieth century and average density of argan trees dropped by around $70 \%$ from 100 to less than 30 trees per hectare (Lybbert et al. 2011). Alifriqui (2004), showed that 240000 ha of argan forest disappeared between 1918 and 1945. In the Souss plain, El Yousfi (1988) showed that $45 \%$ of argan forests were opened to cultivation between 1969 and 1986, which caused the disappearance of 500 ha/year. In the Aoulouz region, the argan forest decreased by $44.5 \%$ and forest density decrease from an average of 27.4 trees/ha to 15.2 trees/ha between 1970 and 2007 (Le Polain de Waroux and Lambin 2012). Germination of argan seedlings is strongly compromised, in fact the seeds harvesting is systematic (Lybbert et al. 2001; Belghazi et al. 2007). Thus, argan trees can be assessed as vulnerable species.

Aromatic and medicinal plants hosted by the argan ecosystem constitute a precious source of income for communities. Production based on the harvesting of wild growing species represents more than $90 \%$ of national production (Zrira 2017). Harvesting is made without any monitoring or scientific support (El Hamdaoui et al. 2018). Today, several medicinal and aromatic plants are becoming rare due to unsustainable methods of harvesting and aridity (Bellakhdar et al. 1991; Benabid 2000; Abouri et al. 2012; Fennane and Rejdali 2016; Lamrani-Alaoui and Hassikou 2018). Among the most harvested and threatened plants in west-central of Morocco it's necessary to cite: T. satureioides, T. leptobotrys, A. herba-alba, M. suaveolens subsp. timija, L. dentata, and Lavandula mairei Humbert. These species should be highlighted as requiring urgent conservation, restoration, and sustainable management attention (Barkaoui et al. 2017; LamraniAlaoui and Hassikou 2018). Indeed, these two plants are popular medicinal herbs in Morocco and are widely exported as herbs or essential oils with currently unsustainable use. 
To protect and conserve argan tree from present overexploitation, it was classified in 1998 as a biosphere Reserve by UNESCO, and many efforts were undertaken by the Moroccan government for its rehabilitation. In 2010, the state created the National Agency for the Development of the Oasis and Argan tree (Agence Nationale pour le Développement des Zones Oasiennes et de l'Arganier (ANDZOA)). ANDZOA aims to realize a sustainable and balanced development within the oasis system and argan forest. This strategy is based on several development actions with regard to restore the argan ecosystem, to carry out or to supervise the realization of projects for the promotion, marketing, and labelling of the products of the argan tree and to encourage scientific research relating to the protection and development of the argan tree and the enhancement of its products. One of the strengths of this strategy is to promote argan tree culture (arganiculture) as a productive activity for alleviate poverty and rehabilitating ecosystems (Perry 2020).

In addition, the combined efforts of the ANDZOA, the High Commission for Water and Forests, and other actors have allowed to reduce the argan forest regression rate. Thus, it went from $10 \%$ between 1987 and 2002 to $4 \%$ between 2002 and 2017 in Essaouira district. Further, in the same district, the artificial forest area has increased by 2,147 in 30 years (Sinsin et al. 2020).

Also, to fight against deforestation and the risk of desertification, the Moroccan government developed 10-year program (2015-2024) through the High Commission for Water and Forests. The main strategic axes of this program for the argan woodlands are (i) fight against desertification, (ii) restauration of forest ecosystems, (iii) conservation and valorization of the argan tree, and (iv) economic development of forest ecosystems.

In the same view of the conservation, the argan tree has been the focus of numerous research and social development projects. In association with the European Union, the Social Development Agency in Morocco has launched the Argan project call in 2003 for a period of five years for a total estimated cost of 12 million euros. Aims of the project were to improve livelihood of rural women trough income generating activities and sustainable management of the argan grove. In addition, a research program for a total amount of 3.7 million dirhams was launched by the agency in 2004 focused on the theme of (i) valuation of argan oil products, (ii) vegetative multiplication and root symbioses of argan tree and optimization of argan ecosystems, (iii) agroforestry, and (iv) natural and human environment. In 2011, for a period of 3 years, the Hassan II Academy of Sciences and Techniques funded a project on genetic and molecular characterization and multiplication by microcuttings of argan tree. Recently, research was oriented toward identifying of high performing genotypes with the capacity to produce quality oil in sufficient quantity and to grow rapidly through the selection and mass propagation. Therefore, with the aim of developing arganiculture, there is an urgent need for applied research and knowledge on qualitative and quantitative potential of the argan tree in terms of yield and quality product (Ait Aabd et al. 2019).

Preservation and valorization of the argan woodlands require the diversification of forest production so that argan woodlands, which have been declared of world heritage value for humanity since 1998, can play their ecological, economic, and social role.

Authors' contributions FM, EHM, and JNF conceived the idea for the article. FM performed the literature search and wrote the paper with contributions from all coauthors. All authors read and approved the final manuscript.

Data availability Not applicable.

\section{Compliance with ethical standards}

Ethics approval and consent to participate Not applicable.

Consent for publication Not applicable.

Competing interests The authors declare that they have no competing interests.

\section{References}

Abouri M, El Mousadik A, Msanda F, Boubaker H, Saadi B, Cherifi K (2012) An ethnobotanical survey of medicinal plants used in the Tata Province, Morocco. Int Med Plant 1(7):099-123

Ait Aabd N, Bouharroud R, Tahiri A, Wifaya A, Mimouni A, El Mousadik A (2019) Genetic Diversity and Breeding of Argan Tree (Argania spinosa L. Skeels). In: Al-Khayri J, Jain S, Johnson D (eds) Advances in Plant Breeding Strategies: Nut and Beverage Crops. Springer, Cham. https://doi.org/10.1007/978-3-030-2311252

Aithammou R, Harrouni C, Aboudlou L, Hallouti A, Mlouk M, Elasbahani A, Daoud S (2019) Effect of clones, year of harvest and geographical origin of fruits on quality and chemical composition of Argan oil. Food Chem 297:124749. https://doi.org/10.1016/ j.foodchem.2019.05.024

Akrout A, El Jani H, Amouri S, Neffati M (2010) Screening of Antiradical and Antibacterial Activities of Essential Oils of Artemisia campestris L., Artemisia herba alba Asso, \& Thymus capitatus Hoff. Et Link. Growing Wild in the Southern of Tunisia. Recent Res Sci Technol 2(1):29-39

Alifriqui M (2004) L'écosystème de l'arganeraie. Actes Sud Rabat

Asdadi A, Hamdouch A, Gharby S, Idrissi Hassani LA (2020) Chemical characterization of essential oil of Artemisia herba-alba asso and his possible potential against covid-19. JAnalyt Sci Appl Biotechnology 2(2):67-72

Aziz L, Mormont M, Allali K (2013) Effets de la marchandisation de l'arganier sur la vie socioéconomique des populations de l'arganeraie marocaine. Vertigo-la revue electronique en sciences de l'environnement 13(1):1-19 
Barbéro M, Quézel P, Rivas-Martinez S (1981) Contribution à l'étude des groupements forestiers et préforestiers au Maroc. Phytocoenologia 9(3):311-412

Barbéro M, Benabid A, Quézel P, Rivas-Martinez S, Santos A (1982) Contribution à l'étude des Acacio-Arganietalia du Maroc occidental. Doc. Phytosociol. n.s. Camérino 6:311-338

Barkaoui M, Katiri A, Boubaker H, Msanda F (2017) Ethnobotanical survey of medicinal plants used in the traditional treatment of diabetes in Chtouka Ait Baha and Tiznit (Western Anti-Atlas) Morocco. J Ethnopharmacol 198:338-350

Belghazi B, Ezzahiri M, El Kharouidet A, Belghazi T (2007) Bilan des nouveaux recépages de l'arganeraie d'Ida ou Throuma (Tamanar) : vitesse de croissance des rejets et vigueur des souches en relation avec le milieu. Annales de la Recherche Forestière au Maroc 38: 106-123

Bellakhdar J, Claisse R, Fleurentin J, Younos C (1991) Repertory of standard herbal drugs in the Moroccan pharmacopoeia. J Ethnopharmacol 35(2):123-143

Benabid A (2000) Flore et écosystèmes du Maroc. Evaluation et préservation de la biodiversité. Ibis Press, Paris

Benabid A, Cuzin F (1997) Des populations de Dragonnier Dracaena draco subsp. ajgal Benabid et Cuzin au Maroc : valeurs taxonomique, biogéographique et phytosociologique. C Acad Sci Paris 320:267-277

Benchekroun F, Buttoud G (1989) L'arganeraie dans l'économie rurale du sud-ouest marocain. Forêt Méditerranéenne 2:127-136

Bennani H, Drissi A, Giton F, Kheuang L, Fiet J, Adlouni A (2007) Antiproliferative effect of polyphenols and sterols of virgin argan oil on human prostate cancer cell lines. Cancer Detect Prev 31:64 69

Berrada Y, Settaf A, Baddouri K, Cherrah A, Hassar M (2000) Experimental assessment of antihypertensive and hypolipidemic effects of oil of Argan, Argania sideroxylon (en). Thérapie (Paris) 55(3):375-378

Berrougui H, Ettaib A, Herrera Gonzalez MD, Alvarez de Sotomayor M, Bennani-Kabchi N, Hmamouchi M (2003) Hypolipidemic and hypocholesterolemic effect of argan oil (Argania spinosa L.) in Meriones shawi rats. J Ethnopharmacol 89:15-18

Boubaker H, Karim H, El Hamdaoui A, Msanda F, Leach D, Bombarda I, Vanloot P, Abbad A, Boudyach EH, Ait Ben Aoumar A (2016) Chemical characterization and antifungal activities of four Thymus species essential oils against postharvest fungal pathogens of citrus. Ind Crop Prod 86:95-101

Boudy P (1958) Economie forestière Nord-Africaine. Larose, Paris

Bourgou S, Bettaieb I, Mkadmini K, Isoda H, Ksouri R, Ksouri WM (2017) LC-ESI-TOF-MS and GC-MS profiling of Artemisia herba-alba and evaluation of its bioactive properties. Food Res Int 99:702-712

Capot-Rey R (1952) Les limites du Sahara français. Trav Inst Rech Sah 8: $23-48$

Chakhchar R, Haworth M, El Modafar C, Lauteri M, Mattioni C, Wahbi S, Centritto M (2017) An assessment of genetic diversity and drought tolerance in argan tree (Argania spinosa) populations : potential for the development of improved drought tolerance. Front Plant Sci 8:276

Charrouf Z, Guillaume D (1999) Ethnoeconomical, ethnomedical, and phytochemical study of Argania spinosa (L.) Skeels. J Ethnopharmacol 67(1):7-14

Charrouf Z, Guillaume D (2008) Argan oil, functional food, and the sustainable development of the argan forest. Nat Prod Commun 3(2):283-288

Chaumat R (1977) Vers une analyse fine d'une limite bioclimatique et floristique : la limite septentrionale du Sahara au Maroc. Doc Carto Ecol Grenoble 19:77-103

Cherki M, Berrougui H, Drissi A, Adlouni A, Khalil A (2006) Argan oil: which benefits on cardiovascular diseases? Pharmacol Res 54:1-5
Coquillard P (1983) Approche phytoécologique d'une enclave saharienne au Maroc oriental : le Tafilalet. Thèse 3ème Cycle, Univ. Nice

Delannoy H (1975) Contribution à l'étude climatologique de la province de Tarfaya. Trav Inst Sc Chérif Fac Sci, Rabat, sér gén 3:15-60

Delannoy H (1980) Remarques sur les brouillards d'été dans quelques stations côtières du Maroc atlantique. Méditerranée 4:37-48

Delannoy H (1988) Précipitations saisonnières du Maroc cisatlasique et téléconnexions dans la circulation atmosphérique. Bull Assoc Géogr Franç Paris 65:393-406

Delannoy H (1996) Remarques sur le climat de la province de Tarfaya. In: l'Harmattan (ed.), Le bassin de Tarfaya, Paléoenvironnement, Paléoanthropologie, Préhistoire: 19-34

Donadieu P (1977) Contribution à une synthèse bioclimatique et phytogéographique au Maroc. Inst.Agron. Vétér. Hassan II, Rabat, rapport interne

Dossa Z (2011) Cooperatives : A development strategy ? An analysis of Argan oil cooperatives in Southwest Morocco, Eurisce Working Paper, N.029/12

Drissi A, Girona J, Cherki M, Godas G, Derouiche A, El Messal M, Saile R, Kettani A, Sola R, Masana L, Adlouni A (2004) Evidence of hypolipemiant and antioxidant properties of argan oil derived from the argan tree (Argania spinosa). Clin Nutr 23:1159-1166

Dubief J (1963) Le climat du Sahara. Mém. Hors série, Univ. Alger, Inst. Rech. Sahariennes, II, fascicule 1

Durán I, Marrero A, Msanda F, Harrouni C, Gruenstaeudl M, Patiño J, Caujapé-Castells J, García-Verdugo C (2020) Iconic, threatened, but largely unknown : biogeography of the Macaronesian dragon trees (Dracaena spp.) as inferred from plastid DNA markers. Taxon. https://doi.org/10.1002/tax.12215

Eddouks M, Maghrani M, Lemhadri A, Ouahidi M-L, Jouad H (2002) Ethnopharmacological survey of medicinal plants used for the treatment of diabetes mellitus, hypertension and cardiac diseases in the south-east region of Morocco (Tafilalet). J Ethnopharmacol 82(2-3): $97-103$

El Abidine A (2003) Le dépérissement des forêts au Maroc : Analyse des causes et stratégies de lutte. Sécheresse 14(4):209-218

El Aboudi A (1987) Etagement de la végétation du jbel Lkest. DEA. "Géographie, Ecologie et Aménagement des montagnes", Univ. Grenoble I

El Aboudi A, Peltier JP, Doche B (1992) La carte de la végétation des Aït Baha (Anti-Atlas occidental) et son intérêt pour l'édaphologie. Feddes Repert 103:121-126

El Babili F, Bouajila J, Fouraste I, Severine Mauret V, Moulis C (2010) Chemical study, antimalarial and antioxidant activities, and cytotoxicity to human breast cancer cells (MCF7) of Argania spinosa. Phytomedicine 17(2):157-160

El Hamdaoui A, Msanda F, Boubaker H, Leach D, Bombarda I, Vanloot P, El Aouad N, Abbad A, Boudyach EH, Achemchem F, Elmoslih A, Ait Ben Aoumar A, El Mousadik A (2018) Essential oil composition, antioxidant and antibacterial activities of wild and cultivated Lavandula mairei Humbert. Biochem Syst Ecol 76:1-7

El Midaoui A, Haddad Y, Couture R (2016) Beneficial effects of argan oil on blood pressure, insulin resistance and oxidative stress in rat. Nutrition 32(10):1132-1137

El Monfalouti H, Guillaume D, Denhez C, Charrouf Z (2010) Therapeutic potential of argan oil : a review. J Pharm Pharmacol 62:1669-1675

El Mousadik A, Petit RJ (1996) High level of genetic differentiation for allelic richness among populations of the argan tree [Argania spinosa (L.) Skeels] endemic to Morocco. Theor Appl Genet 92: 832-839

El Yousfi M (1988) La dégradation de l'arganeraie dans le sud marocain : cas de la forêt d'Admine (Souss) entre 1969 et 1986. Thesis, IAV Hassan II, Rabat.

Emberger L (1925) Le domaine naturel de l'Arganier. Bull de la Société Botanique de France 72(4):770-774 
Emberger L (1939) Aperçu général sur la végétation du Maroc. Commentaire sur la carte phytogéographique au 1/1 500000. Veröff Geobot Inst Rübel Zürich, 14 : Mém. Hors série Soc Sc Nat Phys Maroc 40- 157

Emberger L (1955) Une classification biogéographique des climats. Rev Trav Fac Sci. Montpellier, série bot 7:3-45

Emberger L, Maire R (1932) La végétation de l'Anti-Atlas. CR Acad Sci 194:232-233

Fennane M (1988) Phytosociologie des tétraclinaies Marocaines. Bull Inst Sci Rabat 12:99-148

Fennane M, Ibn Tattou M (1998) Catalogue des plantes vasculaires rares, menacées ou endémiques du Maroc. Bocconea 8:5-243

Fennane M, Rejdali M (2016) Aromatic and medicinal plants of Morocco : Richness, diversity and threats. Bull Inst Sci 38(1):1-16

Grand View Research (2020) Argan oil market size, share \& trends analysis report by type (conventional, organic), by form (absolute, concentrate, blend), by application, by distribution channel, by Region and segment forecasts, éáè-2027. San Francisco, CA : Grand View Research. http:/www.grandviewresearch.com/industry-analysis/ argan-oilmarket Accessed October 30, 2020

Guinet P, Sauvage C (1954) Les hamadas sud-marocaines. Botanique Trav Inst Sc Chérifien Sér Générale 2:75-167

H.C.E.F.L.C.D (2012) Rapports annuels des incendies de forêts et bases de données du Service de la Protection des Forêts, Bilans internes, Haut-Commissariat aux Eaux et Forêts et à la Lutte contre la Désertification. Rabat-Chellah, Maroc

Hilali M, Charrouf Z, Soulhi A, Hachimi L, Guillaume D (2005) Influence of origin and extraction method on argan oil physicochemical characteristics and composition. J Agric Food Chem 53: 2081-2087

Idm'hand E, Msanda F, Cherifi K (2020) Ethnobotanical study and biodiversity of medicinal plants used in the Tarfaya Province, Morocco. Acta Ecol Sin 40:134-144

Imelouane B, El Bachiri A, Ankit M, Khedid K, Wathelet JP, Amhamdi $H$ (2010) Essential oil composition and antimicrobial activity of Artemisia herba-alba asso grown in Morocco. Banat's J Biotechnol I 2:48-55

Ismaili $\mathrm{H}$, Milella L, Fkih-Tetouani S, Ilidrissi A, Camporese A, Sosa S, Altinier G, Della Loggia E, Aquino R (2004) In vivo topical antiinflammatory and in vitro antioxidant activities of two extracts of Thymus satureioides leaves. J Ethnopharmacol 91:31-36

Jamali CA, Kasrati A, Bekkouche K, Hassani L, Wohlmuth H, Leach D, Abbad A (2013) Phenological changes to the chemical composition and biological activity of the essential oil from Moroccan endemic thyme (Thymus maroccanus Ball). Ind Crop Prod 49:366-372

Jaouadi I, Koparal AT, Bostancioglu RB, Yakoubi MT, El Gazzah M (2014) The anti-angiogenic activity of Artemisia herba-alba's essential oil and its relation with the harvest period. Aust J Crop Sci 8: 1395-1401

Karmaoui A (2016) Ecosystem Services of the Argan Forest, the Current State and Trends. Adv Res 8(1):1-13

Katiri A, Barkaoui M, Msanda F, Boubaker H (2017) Ethnobotanical survey of medicinal plants used for the treatment of diabetes in the Tizi n'Test region (Taroudant Province, Morocco). J Pharmacogn Nat Prod 3:130. https://doi.org/10.4172/2472-0992.1000130

Khallouki F, Younos C, Soulimani R, Oster T, Charrouf Z, Spiegelhalder B, Bartsch H, Owen RW (2003) Consumption of argan oil (Morocco) with its unique profile of fatty acids, tocopherols, squalene, sterols and phenolic compounds should confer valuable cancer chemopreventive effects. Eur J Cancer Prev 12(1):67-75

Khallouki F, Voggel J, Breuer A, Klika KD, Ulrich CM, Owen RW (2017) Comparison of the major polyphenols in mature Argan fruits from two regions of Morocco. Food Chem 221:1034-1040

Khouya T, Ramchoun M, Hmidani A, Elmoualij B, Amrani S, Harnafi H, Benlyas M, Filali Zegzouti Y, Nazih EH, Ouguerram K, Alem C (2019) Acute toxicity and antiproliferative and procoagulant activities of fractions derived from Thymus satureioides of theMoroccan High Atlas. S Afr J Bot 121:568-576

Kim SC, Crawford DJ, Francisco-Ortega J, Santos-Guerra A (1996) A common origin for woody Sonchus and five related genera in the Macaronesian islands : molecular evidence for extensive radiation. Proc Nat Acad Sci USA 93:7743-7748

Laaribya S, Alaoui A, Gmira N (2017) The Moroccan forest and sustainable development case of the argan tree (Argania spinosa (L.) Skeels) in Morocco. Biol Divers Conserv 10(2):1-7

Lamrani-Alaoui M, Hassikou R (2018) Rapid risk assessment to harvesting of wild medicinal and aromatic plant species in Morocco for conservation and sustainable management purposes. Biodivers Conserv 27:2729-2745

Le Polain de Waroux Y (2013) The Social and Environmental Context of Argan Oil Production. Nat Prod Commun 8(1):1-4

Le Polain de Waroux Y, Lambin EF (2012) Monitoring degradation in arid and semi-arid forests and woodlands : the case of the argan woodlands (Morocco). Appl Geogr 32:777-786

Lybbert TJ (2007) Patent disclosure requirements and benefit sharing : a counterfactual case of Morocco's argan oil. Ecol Econ 64:12-18

Lybbert TJ, Barrett CB, Conrad JM, Narjisse H (2001) Does resource commercialization induce local conservation ? A cautionary tale from Southwestern Morocco. West J Agric Econ 26(2):561-561

Lybbert TJ, Aboudrare A, Chaloud D, Magnand N, Nash M (2011) Booming markets for Moroccan argan oil appear to benefit some rural households while threatening the endemic argan forest. Proc Natl Acad Sci U S A 108(34):13963-13968

M'hirit O, Benzyane M, Benchekroun F, El Yousfi SM, Bendaanoun M (1998) L'arganier, une espèce fruitière-forestière à usages multiples. Mardaga, Sprimont

Masella R, Giovannini C, Vari R, Di Benedetto R, Coni E, Volpe R, Fraone N, Bucci A (2001) Effects of dietary virgin olive oil phenols on low density lipoprotein oxidation in hyperlipidemic patients. Lipids 36:1195-1202

Mateille T, Tavoillot J, Martiny B, Dmowska E, Winiszewska G, Ferji Z, Msanda F, El Mousadik A (2016) Aridity or low temperatures: what affects the diversity of plant-parasitic nematode communities in the Moroccan argan relic forest? Appl Soil Ecol 101:64-71

Mathez J (1973) Nouveaux matériaux pour la flore du Maroc. Fasc. 2: contribution à l'étude de la flore de la région d'Ifn. CNRS Trav RCP 249:105-120

Médail F, Diadema K (2009) Glacial refugia influence plant diversity patterns in the Mediterranean Basin. J Biogeogr. https://doi.org/10. 1111/j.1365-2699.2008.02051.x

Médail F, Quézel P (1999) The phytogeographical significance of southwest Morocco compared to the Canary Islands. Plant Ecol 140:221244

Médail F, Quézel P, Besnard G, Khadari B (2001) Systematics, ecology and phylogeographic significance of Olea europaea L. ssp. maroccana (Greuter \& Burdet) P. Vargas et al., a relictual olive tree in south-west Morocco. Bot J Linn Soc 137:249-266

Michalet R (1991) Une approche synthétique biopédoclimatique des montagnes méditerranéennes : exemple du Maroc septentrional. Thèse Univ. Joseph Fourier, Grenoble, France

Mohamed AH, El-Sayed MA, Hegazy ME, Helaly SE, Esmail AM, Mohamed NS (2010) Chemical constituents and biological activities of Artemisia herba-alba. Rec Nat Prod 4(1):1-25

Monnier Y (1965) Les problèmes actuels de l'arganeraie marocaine. Revue Forestière Française:750-767

Montanari B (2019) Moroccan Thyme (Thymus satureioides Coss.) : modern and traditional applications. Int $\mathrm{J}$ Prof Holist Aromather $8(1): 31-34$

Montanari B, Bergh SI (2019) A gendered analysis of the income generating activities under the green Morocco Plan : who profits? Hum Ecol 47(3):409-417 
Moukal A (2004) L'arganier, Argania spinosa L. (skeels), usage thérapeutique, cosmétique et alimentaire. De la recherche à la pratique. Phytotherapie 2:135-141

Msanda F (1993) Ecologie et cartographie des groupements végétaux d'Anzi (Anti-Atlas Occidental, Maroc) et contribution à l'étude de la diversité génétique de l'arganier (Arganai spinosa (L.) Skeels). Thèse Univ. Joseph Fourrier, Grenoble, France

Msanda F, El Aboudi A, Peltier JP (2002) Originalité de la flore et de la végétation de l'Anti-Atlas sud-occidental (Maroc). Feddes Repertorium 113(7-8):603-615

Msanda F, El Aboudi A, Peltier JP (2005) Biodiversité et biogéographie de l'arganeraie marocaine Cahiers. Agricultures 14(4):357-364

Naggar M, Mhirit O (2006) L'arganeraie : un parcours typique des zones arides et semi-arides marocaines. Sécheresse 17(1-2):314-317

Nouaïm R, Chaussod R, El Aboudi A, Schnabel C, Peltier JP (1991) L'arganier: essai de synthèse des connaissances sur cet arbre. In: Physiologie des Arbres et Arbustes en Zones Arides et Semi-arides, Groupe d'Etude de l'Arbre, Paris, pp 373-388

Nouaim R, Mangin G, Breuil MC, Chaussod R (2002) The argan tree (Argania spinosa) in Morocco : Propagation by seeds, cuttings and in-vitro techniques. Agrofor Syst 54:71-81

Peltier JP (1982) La végétation du bassin versant de 1 'Ouest Souss (Maroc). Thèse es-sciences Université Scientifique et médicale. Grenoble, France

Peltier JP (1986) L'étage de végétation inframéditerranéen dans le Souss. Doc Phytosoc no 11. Sér 10(1):437-454

Peltier JP, Msanda F (1995) Diversité et originalité de la steppe à Euphorbia officinarum L. subsp echinus (Hooker fil. et Cosson) Vindt du sud-ouest marocain. Feddes Repertorium 106(3-4):215229

Perry W (2020) Social sustainability and the argan boom as green development in Morocco. World Dev Perspect 20:100238. https://doi. org/10.1016/j.wdp.2020.100238

Quézel P (1965) La végétation du Sahara, du Tchad à la Mauritanie. Masson, Paris

Quézel P (1995) La flore du bassin méditerranéen : origine, mise en place, endémisme. Ecol Mediterr 21(1-2):19-39

Quézel P (2000) Réflexions sur l'évolution de la flore et de la végétation au Maghreb méditerranéen. Ibis Press

Quézel P, Barbéro M (1993) Variations climatiques au Sahara et en Afrique sèche depuis le Pliocène : enseignements de la flore et de la végétation actuelles. Bull Ecol 24(2-3-4):191-202

Quézel P, Barbéro M, Benabid A, Rivas-Martinez S (1994) Le passage de la végétation méditerranéenne à la végétation saharienne sur le revers méridional du Haut Atlas oriental (Maroc). Phytocoenologia 22(4):537-582
Ramchoun M, Sellam K, Harnafi H, Alem C, Benlyas M, Khallouki M, Amrani S (2015) Investigation of antioxidant and antihemolytic properties of Thymus satureioides collected from Tafilalet Region, south-east of Morocco. Asian Pac J Trop Biomed 5(2):93-100

Roumane A (2017) Structures coopératives et valorisation économique de la biodiversité cas de la filière d'huile d'argan au Maroc. RECMA 4(346):59-72

Sauvage C (1963) Etages bioclimatiques. Atlas du Maroc Sect II, pl nºb, 1 carte et 2 cartons couleurs. Notice explic

Sguenfle M, Sadki A (2018) The endemic argan tree as a tool for territorial marketing for tourism development in Souss Massa. Int J Sci Manag Tour 4(2):501-519

Sinsin TEM, Mounir F, El Aboudi A (2020) Comparative analysis of spatial-temporal dynamics in the plain and moutain argan ecosystems, Morocco. Int J Environ Stud 10:1080

Taleb MS (2017) Aromatic and medicinal plants in Morocco: diversity and socio-economic role. World Academy of Science, Engineering and Technology International Journal of Agricultural and. Biosyst Eng 11(12):764-768

Tawaha K, Alali FQ, Gharaibeh M, Mohammad M, El-Elimat T (2007) Antioxidant activity and total phenolic content of selected Jordanian plant species. Food Chem 104(4):1372-1378

Tilaoui M, Ait Mouse H, Jaafari A, Zyad A (2015) Comparative phytochemical analysis of essential oils from different biological parts of Artemisia herba alba and their cytotoxic effect on cancer cells. PLoSONE 10(7):e0131799. https://doi.org/10.1371/journal.pone. 0131799

Turner B (2014) Neoliberal politics of resource extraction : Moroccan argan oil. Forum Dev Stud 41(2):207-232

Yaghmur A, Aserin A, Mizrahi Y, Nerd A, Garti N (1999) Argan oil-inwater emulsions: Preparation and stabilization. J Am Oil Chem Soc 76:15-18

Zeggwagh NA, Farid O, Michel JB, Eddouks M (2008) (2008) Cardiovascular effect of Artemisia herba alba aqueous extract in spontaneously hypertensive rats. Methods Find Exp Clin Pharmacol 30(5):375-381

Zrira S (2017) Some important aromatic and medicinal plants of Morocco. M. Neffati et al. (eds.), Medicinal and aromatic plants of the world - Africa Volume 3, Medicinal and Aromatic Plants of the World https://doi.org/10.1007/978-94-024-1120-1_5

Publisher's note Springer Nature remains neutral with regard to jurisdictional claims in published maps and institutional affiliations. 